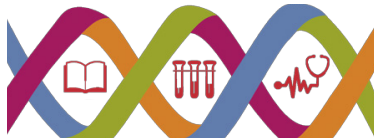 \\ ALERTA \\ Revista clentifica del instituto Nacional de Salud
}

\section{Nocardia spp causante de neumonía bacteriana}

Abel Antonio Godoy ${ }^{1}$, Óscar Grande ${ }^{1}$, Reina Villatoro ${ }^{1}$

${ }^{1}$ Laboratorio Nacional de Referencia del Instituto Nacional de Salud (INS)

Recibido: 2 de marzo de 2018 Aceptado: 16 de marzo de 2018

Correspondencia: godoy0287@gmail.com

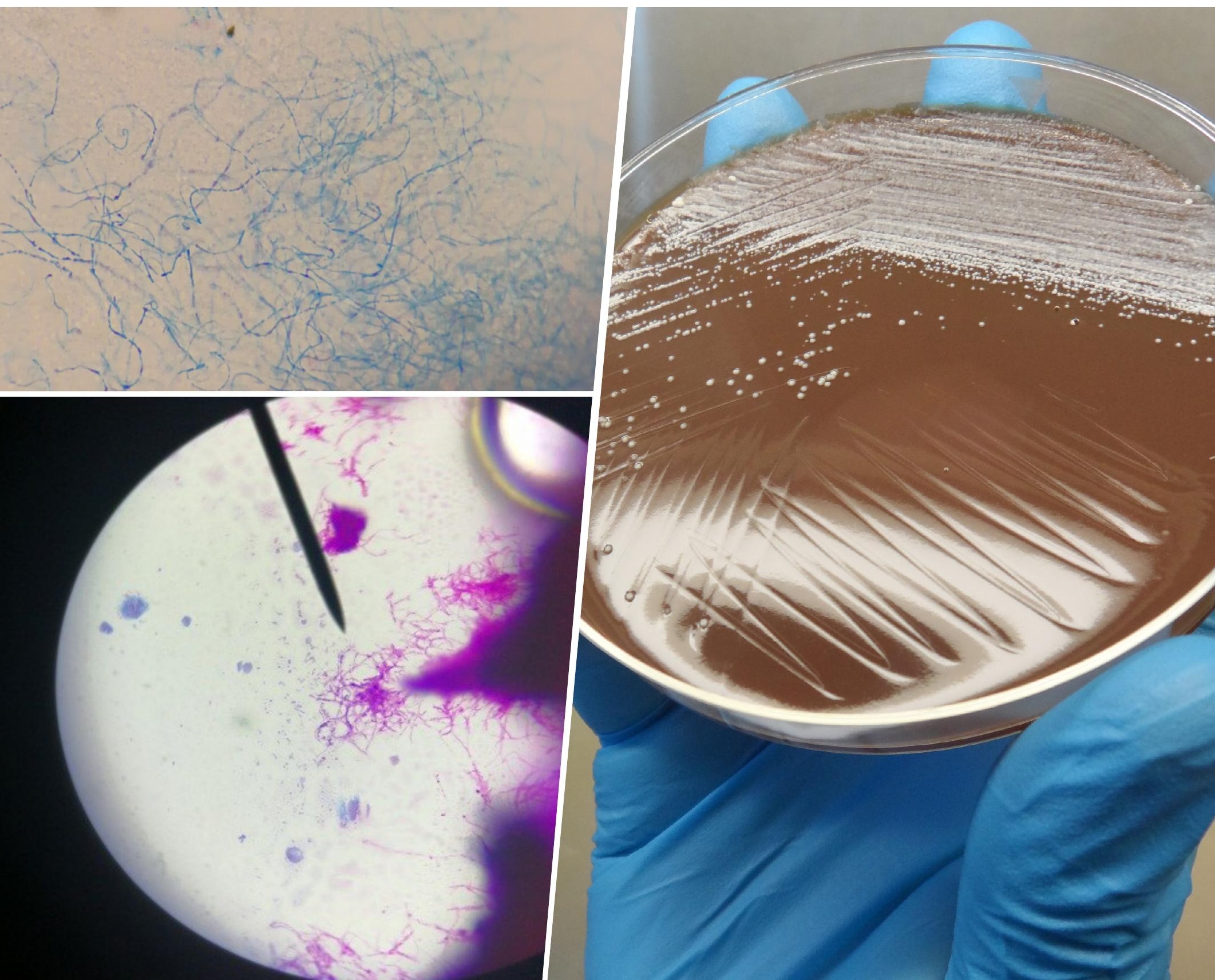


El género Nocardia fue aislado y reconocido como patógeno por primera vez por el veterinario francés Edmundo Nocard, en 1888, en una epidemia de muermo bovino. En 1891 describe el primer caso de nocardiosis humana en un paciente con síndrome pseudotuberculoso. Este género pertenece al orden de los Actinomycetales ${ }^{1}$. Se reconocen 18 especies de los cuales 11 causan enfermedad en humanos; de ellas, las tres más frecuentes que causan infección en el hombre son: N. asteroides, N. Brasiliensis, N. caviae, y N. otitidiscaviarum².

Existen dos tipos básicos de enfermedad en el hombre causadas muy frecuentemente por $N$. asteroides, provocando una infección pulmonar primaria. De manera recurrente, esta se disemina a través del torrente sanguíneo y linfático a otras partes del cuerpo. Sin embargo, también puede ser inicialmente una enfermedad del sistema nervioso central, riñones, ojos u otros órganos. Por otro lado, los micetomas por Nocardia, son generalmente causados por $N$. brasiliensis².

Es un microorganismo ramificado, filamentoso, gram positivo y débilmente ácido, clasificado como actinomicetos aeróbicos ${ }^{2}$. Son ubicuos en el medio ambiente, pero se encuentran principalmente en climas secos y cálidos $^{3}$ y generalmente afecta a pacientes inmunodeprimidos, oncológicos, transplantados y en tratamiento con corticoides. Esto ha llevado a un incremento en las infecciones por gérmenes que raramente afectan a pacientes inmunocompetentes, como ocurre en el caso de la infección pulmonar por Nocardia $s p^{4}$. Esta se adquiere a través del tracto respiratorio, siendo $N$. asteroides el microorganismo aislado más frecuente ( $85 \%$ de aislamientos) ${ }^{5}$.

En la sección de bacteriología del Laboratorio Nacional de Referencia (LNR) se recibió una cepa bacteriana en medio Lowenstein-Jensen (Figura 1), para identificación de género y especie obtenida de un cultivo de muestra de macerado pulmonar ${ }^{6}$ de un paciente de 57 años, con tipo de infección nosocomial. Se realizó cultivo en agares nutritivos, coloración de Gram y tinción de Ziehl-Neelsen.

Se cultivó en agar sangre, agar chocolate (Figura 2,3) y agar tripticasa soya. Se incubó a $35^{\circ} \mathrm{C} \pm 2$ por cuatro días en aerobiosis; se desarrollaron colonias elevadas rugosas color amarillentas y se realizaron pruebas bioquímicas, mostrando ser oxidasa y catalasa positivo, úrea positivo, movilidad negativo, agar tres azúcares y hierro con resultado $\mathrm{K} / \mathrm{K}$ sin producción de gas y H2S, agar Citrato de Simmons negativo. En la coloración de gram se observaron bacilos gram positivos filamentosos ramificados. En la tinción de ZiehlNeelsen (Figura 5,6) se observaron bacilos ramificados, parcialmente alcohol ácido resistentes ${ }^{1}$. El resultado se concluye que se trató de una cepa de Nocardia sp por identificación fenotípica y microscópica.

\section{Referencias bibliográficas}

1. Bellésa VL, Vicente RF. Nocardia asteriodes [Internet]. Control calidad SEIMC; Disponible en: https://www.seimc.org/contenidos/ ccs/revisionestematicas/bacteriologia/nocardia.pdf

2. Serrano JA, Sandoval AH. Identificación y Diagnóstico de Actinomicetales Patógenos [Internet]. primera edición. Venezuela: Publicaciones del Vicerrectorado Académico Colección Ciencias de la Salud; 256 p. (Colección Ciencias de la Salud; vol. 1). Disponible en: http://www.saber.ula.ve/bitstream/handle/123456789/32979/ libro_\%20completo.

3. Shirani K, Poulsen AN, Hakamifard A. Nocardial brain abscess in a patient with pulmonary alveolar proteinosis. Adv Biomed Res. 2015;4:185.

4. Curry WA. Human nocardiosis. A clinical review with selected case reports. Arch Intern Med. junio de 1980;140(6):818-26.

5. Menéndez R, Cordero PJ, Santos $M$, Gobernado $M$, Marco V. Pulmonary infection with Nocardia species: a report of 10 cases and review. Eur Respir J. julio de 1997;10(7):1542-6.

6. Peña M C, Césped G M, Wolff R M, Álvarez V F, Garay B C, Medina $\mathrm{P} M$, et al. Diagnóstico bacteriológico de tuberculosis pulmonar mediante fibrobroncoscopía en pacientes con VIH. Revista chilena de enfermedades respiratorias. marzo de 2014;30(1):46-53.

\section{Forma recomendada de citar}

Godoy A, Grande Ó, Villatoro R. Nocardia spp. causante de neumonía bacteriana. Revista ALERTA. 2018; 1 (1): 69-71 


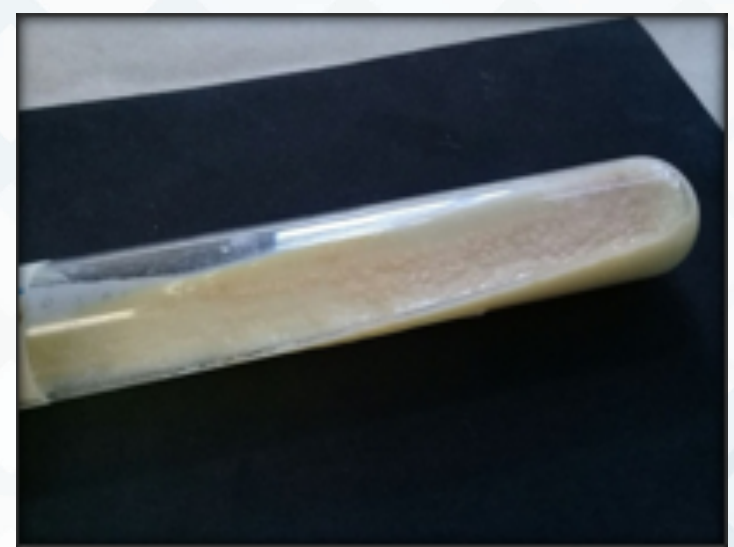

Figura 1: Crecimiento de Nocardia medio LowensteinJensen 10 días de incubación $35^{\circ} \mathrm{C} \pm 2$.

Fuente: LNR - Sección Bacteriología.

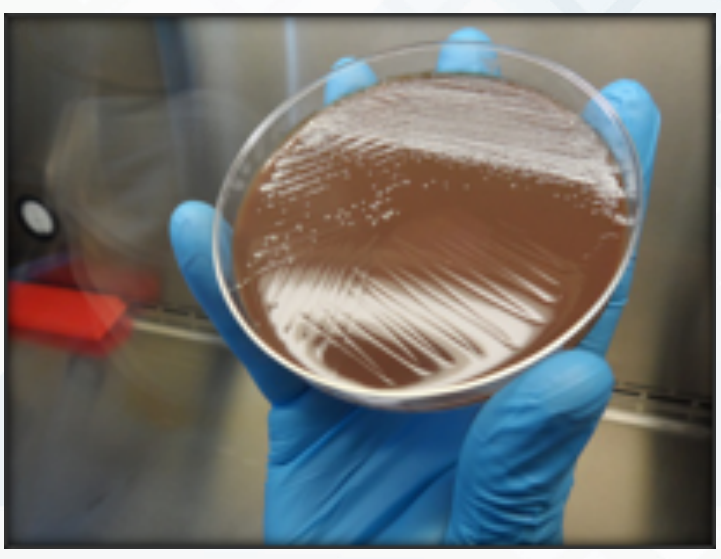

Figura 3: Crecimiento de Nocardia en agar chocolate incubado $96 \mathrm{~h}$ a $35^{\circ} \mathrm{C} \pm 2$, Fuente: LNR - Sección Bacteriología.

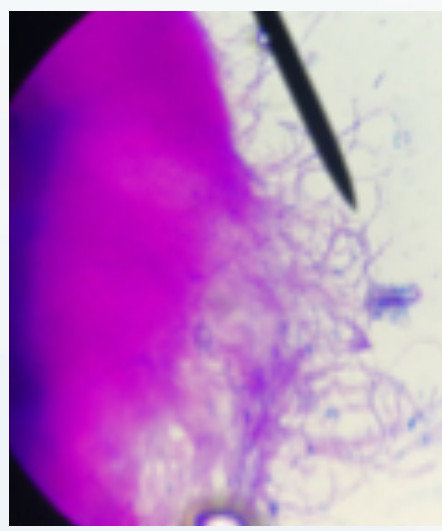

Figura 5: Tinción de Ziehl-Neelsen: bacilos parcialmente alcohol ácido resistentes ramificados. Fuente: LNR - Sección Bacteriología.

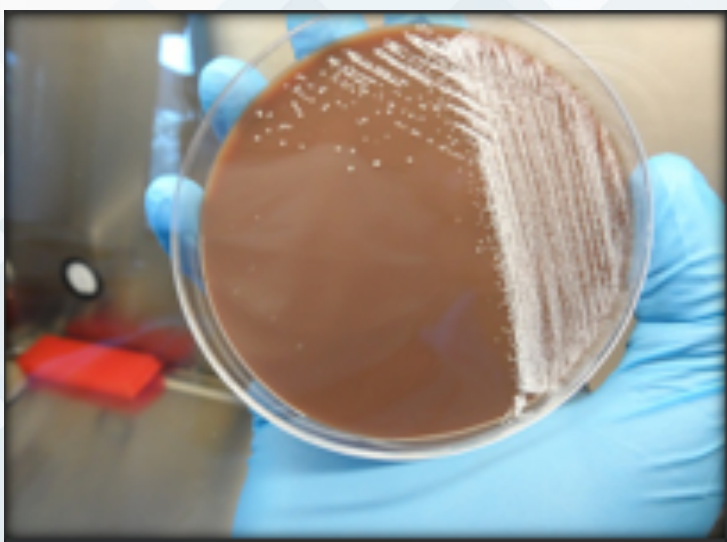

Figura 2: Crecimiento de Nocardia en agar chocolate incubado $96 \mathrm{~h}$ a $35^{\circ} \mathrm{C} \pm 2$. Fuente: LNR - Sección Bacteriología.

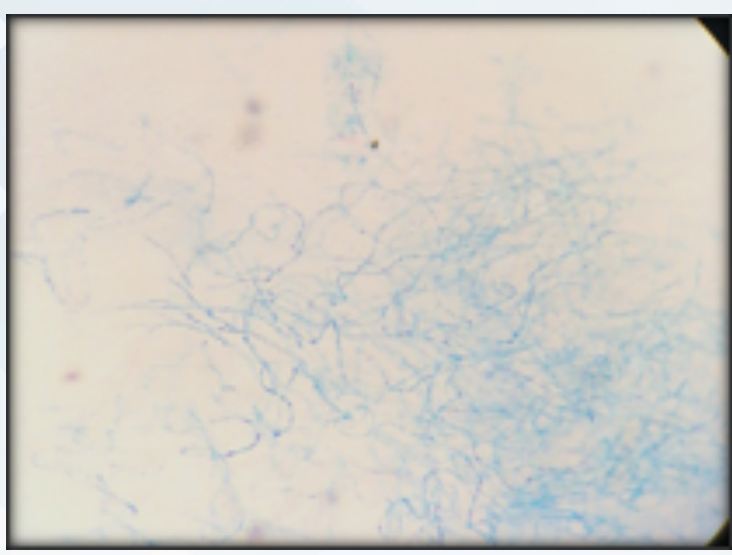

Figura 4: Coloración de Gram: bacilos grampositivos ramificados.

Fuente: LNR - Sección Bacteriología.

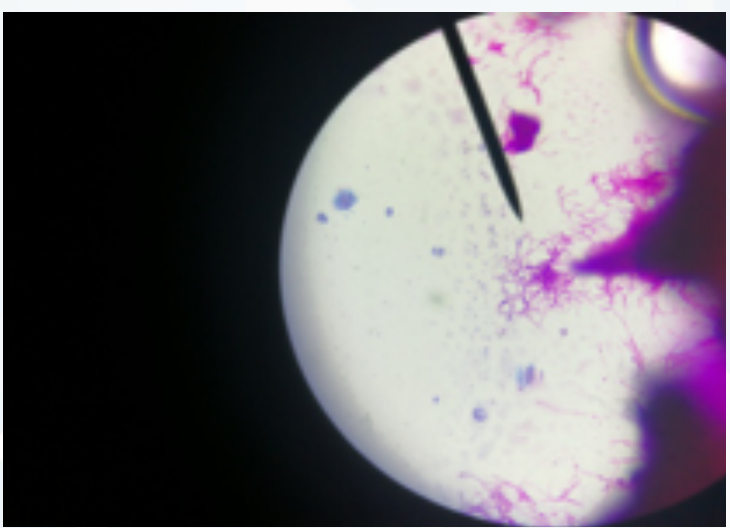

Figura 6: Tinción de Ziehl-Neelsen: bacilos parcialmente alcohol ácido resistentes ramificados. Fuente: LNR - Sección Bacteriología. 